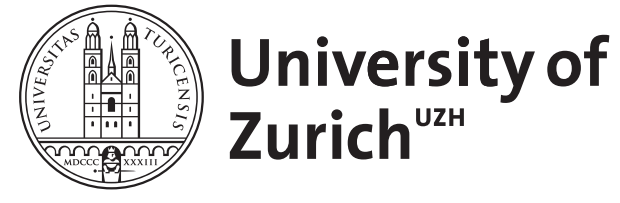

\title{
Glacier changes since the Little Ice Age
}

\author{
Paul, Frank ; Bolch, Tobias
}

\begin{abstract}
The majority of glaciers are currently retreating globally but had been in an advanced position for several hundred years during the so-called Little Ice Age (LIA). During this period, the lateral accumulation of rock and debris created impressive moraine walls. Between these LIA moraines and the actual terminus position is the glacier forefield, which is growing as glaciers retreat. Whereas the forefields are constantly changing (e.g. due to the transport of sediment and rock, lake formation and growth, plant colonization), the outer boundary marked by the moraines changed little and has widely been used to reconstruct maximum LIA extents and volume for numerous glaciers around the world. Together with field and satellite measurements, a detailed time series of glacier fluctuations since the LIA has been obtained for hundreds of glaciers that indicate some regional and glacier-specific variability, but also robust global trends of shrinkage and volume loss. Overall, the kilometre-scale retreat and upward shift of glacier termini by several $100 \mathrm{~m}$ since the end of the LIA confirm a global temperature increase by about one degree. As most glaciers have not yet adjusted their geometry to current climatic conditions, they will further shrink while forefields will continue to grow.
\end{abstract}

DOI: https://doi.org/10.1007/978-3-319-94184-4_2

Posted at the Zurich Open Repository and Archive, University of Zurich

ZORA URL: https://doi.org/10.5167/uzh-178345

Book Section

Accepted Version

Originally published at:

Paul, Frank; Bolch, Tobias (2019). Glacier changes since the Little Ice Age. In: Heckmann, Tobias; Morche, David. Geomorphology of Proglacial Systems : Landform and Sediment Dynamics in Recently Deglaciated Alpine Landscapes. Cham: Springer, 23-42.

DOI: https://doi.org/10.1007/978-3-319-94184-4_2 


\title{
Glacier changes since the Little Ice Age
}

\author{
Frank Paul ${ }^{1}$, Tobias Bolch ${ }^{l}$ \\ ${ }^{1}$ Department of Geography, University of Zurich, Zurich, Switzerland
}

\begin{abstract}
Glaciers are currently retreating globally but had been in an advanced position for several hundred years during the so-called Little Ice Age (LIA). During this period the lateral accumulation of rock and debris created impressive moraine walls. Between these LIA moraines and the actual terminus position is the glacier forefield, which is growing as glaciers retreat. Whereas the forefields are constantly changing (e.g. due to transport of sediment and rock, lake formation and growth, plant colonization), the outer boundary marked by the moraines changed little and has widely been used to reconstruct maximum LIA extents and volume for numerous glaciers around the world. Together with field and satellite measurements a detailed time-series of glacier fluctuations since the LIA has been obtained for hundreds of glaciers that indicate some regional and glacier-specific variability, but also robust global trends of shrinkage and volume loss. Overall, the kilometre-scale retreat and upward shift of glacier termini by several $100 \mathrm{~m}$ since the end of the LIA confirm a global temperature increase by about one degree. As most glaciers have not yet adjusted their geometry to current climatic conditions, they will further shrink while forefields will continue to grow.
\end{abstract}

\section{Introduction}

In most regions of the world, glaciers reached a Holocene maximum extent at the end of the so-called Little Ice Age (LIA) and decreased in size more or less continuously afterwards (Grove 2004). This maximum extent was not reached everywhere at the same point in time. For example, in the Alps this was during the $17^{\text {th }}$ to $19^{\text {th }}$ century (often around 1820 or 1850 ), in Scandinavia in the mid- $18^{\text {th }}$ century and in New Zealand or parts of Alaska in the early $18^{\text {th }}$ century (Rabatel et al. 2008). The LIA is understood as a slightly cooler period in the Holocene, lasting from about 1300 to 1850 that is often explained by a reduced solar activity (e.g. the Maunder Minimum) along with increased volcanism and internal climatic variability over this period (Grove 2004; Wanner et al. 2008). However, the period was neither geographically nor temporarily homogenous at a global scale and details of the precise timing are still a matter of research (Matthews and Briffa 2005). Dating of moraines and reconstructions from a variety of sources such as pictorial and written documents revealed a detailed chronology of glacier fluctuations over the LIA period for selected glaciers in the Alps (e.g. Zumbühl and Holzhauser 1988; Nussbaumer et al. 2007), Norway (Nussbaumer et al. 2011a) or Patagonia and South America (Masiokas et al. 2009a and b). In general, terminus fluctuations during the period of maximum extent were within a few hundred meters. The exact timing and amplitude of these fluctuations is glacier specific, e.g. a function of glacier size and slope as well as topographic conditions (e.g. hypsometry and shading) and mass balance sensitivity.

After 1850 however, glaciers globally decreased in size and volume and their fronts retreated by up to a few kilometres for the largest (land-terminating) glaciers (Oerlemans 2005; Vaughan et al. 2013) in response to a general increase in temperature. For smaller and more quickly adjusting glaciers, intermittent phases of re-advance were observed in several regions in the 1930s and 1980s (e.g. Alps, Alaska, Tropics) and 1990s (e.g. Norway, New Zealand, Caucasus), but the specific reasons for these fluctuations might have been different (Chinn et al. 2005; UNEP 2007; Zemp et al. 2015). In the Alps, some glaciers advanced several hundred metres during these periods, but none reached again the LIA maximum extent. Moreover, the 1970s advances did by far not reach the one from the 1930s advance so that glacier 
forefields (i.e. the ice-free terrain between the current glacier terminus and the 1850 s maximum extent) show two further terminal moraine walls within the 1850s extent, a bigger one from the 1930s and a smaller one from the 1970 s to 1980 s (Fig. 1). Outside but very close to the extent from around 1850, glaciers in the Alps and elsewhere have further lateral or terminal moraines from the LIA period. They reveal larger glacier extents before 1850 as they were not buried by the latest advance. In the Alps these are seldom well preserved and are only slightly larger than the 1850 extent (Fig. 2) so that the latter is often taken as a synonym for the maximum extent of the entire LIA. In other regions, however, this is wrong, as former extents (e.g. mid- $18^{\text {th }}$ century in Scandinavia or mid- $17^{\text {th }}$ century in Patagonia) were much larger than the mid- $19^{\text {th }}$ century extents (Nussbaumer et al. 2011a; Masiokas et al. 2009a). Hence, the '1850s maximum extent' mentioned above and in the following is only the latest LIA maximum extent, but often not the largest one in absolute terms. As the lateral LIA moraines from the latest advance are still comparably well preserved and often have vegetation free inner sides, they can be identified on medium resolution (Landsat-type) optical satellite imagery and related extents can be mapped (Paul and Kääb 2005; Wolken 2006).

In response to a strong increase in global temperature around 1985 (Beniston 2006; Wild et al. 2007; Reid et al. 2016), glacier mass loss increased in many regions of the world (Zemp et al. 2009). As an immediate reaction, glaciers lost mass by surface lowering in the ablation area (Paul and Haeberli 2008). Additionally, several glaciers also started thinning in their upper parts, indicating a disequilibrium response where glaciers will ultimately melt away completely (Pelto 2010). For the time being, the accumulation area of glaciers is too small to sustain their current size and they will thus continue shrinking (Carturan et al. 2013b). This so-called committed area and volume loss will reduce the size of current glaciers by a further 30 to $60 \%$ within the next few decades, even without a further increase in temperature (Dyurgerov et al. 2009; Zemp et al. 2015).

With constantly shrinking glaciers, their forefields constantly grow. If not taken over by lakes that form between the glacier terminus and the LIA moraine or in local overdeepenings of the bedrock (e.g. Haeberli et al. 2016b; Loriaux and Casassa 2013), the forefields provide new land where soil can develop (Egli et al. 2006) and vegetation can grow (Heckmann et al. 2016). Despite a large amount of studies that have reconstructed LIA glacier extents, little is known about the geomorphological and geomorphometric characteristics of the glacier forefields and their genesis over the past century, maybe apart from a few well-studied cases (see Chapter 3.2 of this book).

As a more glaciological background to glacier forefields, this study provides an overview on the response of glaciers to climate change with a focus on the centennial time scale (Section 2), observation of glacier fluctuations from the ground and from space (3), the observed glacier changes since the LIA on a global scale and for the Alps (4), and a discussion on potential future changes and related developments of glacier forefields (5).

\section{Glacier response to climate change}

\subsection{Glacier formation and climate}

As glaciers originate from compressed snow, they can be found where climate conditions allow snow to survive summer melting and later accumulation over several decades. This results in three main factors required to build a glacier: temperatures must be sufficiently low so that precipitation falls in solid form and accumulates, precipitation must be sufficiently high that snow survives the summer melting (higher amounts can compensate higher temperatures), and there must a place for the snow to accumulate. Such conditions are found in moun- 
tain and polar regions whenever terrain is not too steep. Otherwise snow will be transported downwards by avalanches and either contribute to glacier nourishment or melt. Hence, mountains must be high enough to receive solid precipitation that does not melt, i.e. towards warmer climatic zones mountains must be higher to be glacier covered. Also the amount of precipitation and several other factors play a role (e.g. von Humboldt 1845). When it is cold enough (e.g. in Arctic regions) also sparse precipitation can sustain glaciers. In Fig. 3 a map of global glacier distribution is shown with the colour-coding representing their mean elevation, as averaged from the global glacier inventory (Pfeffer et al. 2014) over the respective region. Lower mean elevations towards polar and more maritime regions can be clearly recognized.

Once glaciers are in place, their further existence depends on the balance between the mass gained by snow fall at their higher elevations (accumulation region) and the mass loss by melting and probably calving in their lower reaches (ablation zone). Thereby, the ice is constantly transported downwards by glacier flow. The mass balance is variable from year to year, and only long-term trends (decadal scale) in accumulation and/or ablation have finally an impact on glacier geometry. If over such a long period in nearly all years more ice is lost than replaced by glacier flow from the accumulation region, glaciers adjust their size to the new climatic conditions by shrinking (and vice versa for advance). This can take several decades, depending on the amplitude of the governing climate change and the size/slope of the glacier governing its response time (Oerlemans 2001). In effect, the resulting changes in glacier length can be seen as a delayed and smoothed, but also enhanced response to a longer-term (decadal to centennial scale) change of the climate, whereas the annual mass balance reflects the atmospheric conditions of the respective year and is thus the undelayed and direct response to the atmospheric forcing of that year (with possibly large variability from year to year). Hence, the response of a glacier to climate change (i.e. a trend over several decades) is becoming visible by its advance or retreat, which can be measured in the field and is widely recognized by the public (see 2.3 ).

\subsection{Mass balance terms (ELA and AAR)}

A key indicator for the annual conditions is the so-called equilibrium line (EL) that is dividing the accumulation region (above it) of a glacier from the ablation region (below it) and defined by a zero mass balance (i.e. mass gain equals mass loss). For mid-latitude glaciers, this line is roughly located at the boundary between the snow-covered and the bare ice region on a glacier. At the end of the summer (or the ablation period) the elevation of this boundary gives a good approximation of the annual mass balance as mass loss by melting linearly decreases with elevation for most glaciers (Oerlemans 2001). At a specific altitude of the EL, the mass balance averaged over the entire glacier (also called glacier-wide mass balance) is zero. This

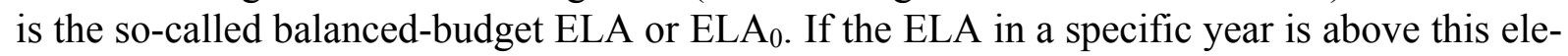
vation, the mass balance will be negative (or positive if lower). The $\mathrm{ELA}_{0}$ can be derived from mass balance measurements performed over several years and is approximately located at the mid-point elevation (maximum + minimum elevation / 2) of a glacier (Braithwaite and Raper 2009) or where $60 \%$ of the glacier area is above it and $40 \%$ below it (Bahr et al. 2009). For tropical and polar glaciers or glaciers mainly nourished by snow avalanches these simple relations do not apply.

For mid-latitude glaciers (dominated by winter accumulation and summer ablation) the snowcovered area at the end of the ablation period can be used as a proxy for the accumulation area and the elevation of the snowline as a proxy for the EL. For glaciers with a known relationship between mass balance and the EL, snow lines (e.g. derived from satellite data) can be used to estimated glacier mass balance (e.g. Rabatel et al. 2005). Whereas the ELA $A_{0}$ is a function of climate and varies greatly among different mountain ranges (Pfeffer et al. 2014), the $\mathrm{AAR}_{0}$ depends on the characteristics of the glacier and varies only between 0.4 and 0.7 (Dy- 
urgerov et al. 2009). In general, a glacier is adjusting its geometry to climate change until annual AAR values over a longer period resemble the $\mathrm{AAR}_{0}$. For small glaciers in lesser mountain ranges an increase of the $\mathrm{ELA}_{0}$ above their highest elevation will ultimately lead to their disappearance. Figure 4 is illustrating the response of glacier geometry to climate change (increase of ELA) schematically for glaciers of different size.

\subsection{Glacier response to climate change}

The required adjustment can also be used quantitatively. For example, if we assume that temperature is increasing by 1 degree and precipitation is about constant, the ELA would approximately increase by about $150 \mathrm{~m}$ (given a mean $0.65 \mathrm{~K}$ per $100 \mathrm{~m}$ temperature lapse rate). To retain this as the mid-point elevation, the glacier terminus needs to shift upwards by about 300 $\mathrm{m}$ (twice as much for purely geometric reasons). Assuming that the glacier bed of a larger valley glacier is only weakly inclined (e.g. Linsbauer et al. 2012), for example 15 degrees, the tongue would retreat by about $1.1 \mathrm{~km}$ for a one degree temperature increase. When this retreat occurs over a period of about 100 years, the glacier would retreat $110 \mathrm{~m}$ per decade for a temperature increase of 0.1 degree over the same period. This strong change in extent for a small change in climate is one reason for naming glaciers sensitive climate indicators. Whereas a $0.1{ }^{\circ} \mathrm{C}$ increase in temperature over a ten-year period is difficult to measure (and to prove for a sceptic public), a $110 \mathrm{~m}$ retreat $\left(11 \mathrm{~m} \mathrm{a}^{-1}\right)$ can be accurately measured and is well recognizable by a large public. Indeed, only few glaciers retreat constantly and the amplitude of the change is smaller for smaller glaciers, but the principle is the same and changes smaller than $11 \mathrm{~m} \mathrm{a}^{-1}$ can be precisely determined as well.

For glaciers with a known $\mathrm{AAR}_{0}$, its value can be used in a simple model to determine glacier-specific area changes for a given temperature change (Paul et al. 2007). This requires calculation of the area-elevation distribution (hypsometry) for each glacier and reducing the size of the respective accumulation area by the given shift of the ELA $\mathrm{A}_{0}$. For an assumed $\mathrm{AAR}_{0}$ of 0.6 the new total area is the size of the resulting new accumulation area divided by 0.6 . A simple summing up of the area in each elevation bin from top to bottom until this size is reached provides the new minimum elevation that can be used in a GIS to delete all glacier cells below this elevation. This allows visualizing the new glacier extent and at the same time the region that will get ice free in the future, i.e. the new glacier forefield (Paul et al. 2007). More complex methods have been developed in the past, which also consider an estimated bedrock topography, glacier flow dynamics and a transient climatic forcing (Huss and Hock 2015; Clarke et al. 2015; Radić and Hock 2011). Such models allow consideration of changes in precipitation and other climatic variables that might delay or enhance glacier shrinkage. So far unconsidered in these models is the reduction of melt and the related delay of the response for strongly debris-covered glaciers, or the change of the radiation balance due to the geometric change.

The above approach is also inverted, i.e. changes in observed glacier extents are used as a proxy to derive the related changes in ELA and thus climate (e.g. Porter 1975; Seltzer 1994).

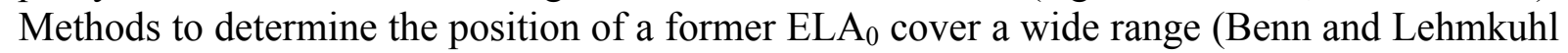
2000) and are in particular popular for reconstruction of temperature depressions during the Holocene, e.g. glacier advances in the Younger Dryas period (e.g. Ivy-Ochs et al. 2009; Kerschner and Ivy-Ochs 2008; Solomina et al. 2015). Thereby, the interplay with changes in precipitation (and radiation) is important (see Kuhn 1981 for details) but difficult to estimate for this time period. When applied to global glacier shrinkage from 1850 to the 1970 s, the observed glacier retreat of a few kilometres for the largest glaciers and the increase in minimum elevation of a few hundred meters roughly corresponds to a $120-150 \mathrm{~m}$ increase of the ELA, thus confirming a related one degree temperature increase over this period. This value varies from glacier to glacier and region to region, but the global picture is rather homogenous and 
consistent in this regard (WGMS 2008). From a dynamic point of view one can note that most glaciers (except the largest ones) adjusted their extents to the warmer climate conditions after 1850 until their re-advance phases occurred, e.g. in the Alps around the 1930s and 1970s to

\section{Glacier observations from the ground and space}

\subsection{Ground-based information}

Systematic and coordinated monitoring of glacier fluctuations (front variations or length changes) with annual temporal resolution was initiated back in 1893 at the 6th Geological Congress in Zurich with a sample of a few hundred glaciers globally. This sample increased to more than 900 for a few decades (1960 to 1990) and is now back to about 600 (Zemp et al. 2015). For a few dozen glaciers information on their terminus fluctuations is also available since 1850, but often not with annual resolution (WGMS 2008; Vaughan et al. 2013). Since 1986 the World Glacier Monitoring Service (WGMS) is in charge of collecting and disseminating information on glacier fluctuations (front variations and mass balances) in a standardized format as provided by a global network of national correspondents and observers in the field (WGMS 2015 and earlier versions, wgms.ch/ggcb). Detailed information about the methods used to perform the measurements and the observed fluctuations can be found in WGMS (2008) or online at www.grid.unep.ch/glaciers. With each year being added, the time series becomes more and more valuable for numerous applications, including process understanding, climate change detection, model calibration, and others.

Detailed reconstructions of earlier glacier fluctuations are based on indirect evidence (such as paintings, dated moraines and dendrochronology) and have been compiled for several regions such as southern Scandinavia (Nussbaumer et al. 2011a), the Canadian Rocky Mountains (e.g. Luckman 2000, Koch et al. 2007), South America (e.g. Jomelli et al. 2009; Masiokas et al. 2009b, Rabatel et al. 2013) and the Alps (Maisch et al. 2000; Zumbühl et al. 2008). For the latter two regions reconstructions go partly back into the $16^{\text {th }}$ century (Zemp et al. 2011 and references therein). Röthlisberger (1986) gives an overview on glacier fluctuations of the past 10000 years for selected glaciers globally. The focus in this comprehensive book is on dating past glacier extents with dendrochronology to obtain a time series of glacier fluctuations. For some of the glaciers not only the frontal position (one dimensional information), but also the lateral extent has been reconstructed, allowing a two-dimensional (2D) view at the former glacier area, at least for their lowermost parts (e.g. Zumbühl and Holzhauser 1988). To date, only few of the reconstructed 2D LIA maximum extents (and their changes afterwards) are digitally available and most of the information is stored on printed maps (e.g. Grove 2004).

Somewhat more qualitative information about former terminus positions (1D information) has been derived over a period of several thousand years for a couple of glaciers in Norway (Nesje et al. 2008a) and the Swiss Alps using lake sediments and dendrochronology (Hormes et al. 2001; Holzhauser et al. 2005; Joerin et al. 2006). The studies for the Alps indicate that 
glaciers had a maximum extent similar to the LIA in the $6^{\text {th }}$ century and were somewhat less extensive (1930s position) around 2600 years ago. In-between these periods the large valley glaciers had likely been smaller than today. How much smaller is difficult to say as minimum extents seldom provide quantitative evidence. During the middle Holocene (about 6000 to 7000 years ago) glaciers might have even completely disappeared as shown for several regions in Norway (Nesje et al. 2008b) or former glacier forefields - currently still covered by glaciers - might have allowed trees to grow (Joerin et al. 2008). In contrast, there is evidence from the Alps or the Canadian Rocky Mountains and other places that ice cover at high elevation sites is now smaller than over the past 5500 years (e.g. Baroni and Orombelli 1996; Koch et al. 2014), indicating that the mid-Holocene warm period was followed by a continuously cooler period already mentioned above (Wanner et al. 2008). As pointed out by Koch et al. (2014), this is remarkable given that only a few hundred years before a Holocene maximum extent had been reached. Hence, at the time scale of centuries glacier forefields are a very dynamic and constantly changing phenomenon.

\subsection{Space-based information}

Satellite images provide a different and largely complimentary access to the reconstruction of glacier fluctuations. Compared to ground based information they cover a shorter time period (e.g. Landsat Multi-Spectral Scanner (MSS) since 1972, Thematic Mapper (TM) since 1984) and they are not available in each year for a specific region (e.g. due to clouds or acquisition strategy). Furthermore, freely available satellite data with a long record such as Landsat have a limited spatial resolution (MSS: $79 \mathrm{~m}$, TM: $30 \mathrm{~m}$ ) that only allows following changes with reduced temporal resolution (e.g. every 5-10 years, depending on the rate of change). These disadvantages are compensated by the complete spatial coverage of a region, i.e. all glaciers in a region are captured rather than only a few selected ones with easy ground access.

Satellite images are mostly used for mapping of glacier extents (i.e. outlines) rather than front variations, but this has been done as well (see 4.1.1). As the information is available in regions or for time periods that are not covered by ground-based information, satellite data can complement existing datasets in this regard (e.g. Barandun et al. 2015). An important advantage of satellite images is that clean glacier ice can be classified automatically using a simple band ratio (e.g. dividing the red by the short-wave infrared band) and a threshold for segmentation into a binary map. This map can henceforth be transformed to glacier outlines using raster-vector conversion (Paul 2002 and 2015; Bolch and Kamp 2006). For the 30-year period with available Landsat data such outlines have been generated for many regions in the world for multiple points in time (Bolch et al. 2010a; Paul and Mölg 2014; Narama et al. 2010), forming a base for our understanding of climate change impacts globally.

On the other hand, only few studies have yet explored the large potential of satellite data to map LIA extents by digitizing moraines and trimlines (Baumann et al. 2009; Citterio et al. 2009; Davies and Glasser 2012; Loibl et al. 2014). This might be related to the time consuming manual mapping, the limited spatial resolution, the unknown timing of the LIA extent, and because evidence of LIA extents might not be visible for all glaciers, among other factors. At least the spatial resolution of (freely available) sensors is constantly increasing (now at 10 $\mathrm{m}$ with Sentinel 2) and commercial high-resolution images (along with aerial photography) have been used for this purpose as well (e.g. Fischer et al. 2015; Solomina et al. 2016). As an intermediate solution, images in Google Earth can be used to verify the interpretation of freely available but coarser resolution satellite images. As mentioned above, the timing of the maximum extent varies (Rabatel et al. 2008), but is rather homogenous for a larger mountain range as temperature trends (driving the long-term variability) are similar over a few hundred $\mathrm{km}$ (Böhm et al. 2001). However, the small-scale variability in precipitation can impact on the magnitude and timing on a shorter (decadal) time scale. As only rates of relative area changes 
are comparable among different regions, the timing of the mapped extent has to be approximated as good as possible (e.g. from maybe available field measurements of length changes). Overall, the digital LIA extent dataset is growing and its current limited availability will improve in the future.

\section{Glacier changes since the Little Ice Age}

\subsection{A global overview}

Numerous local to regional scale studies on glacier changes since the LIA have been peris the book "Little Ice Age" by Jean M. Grove, published in 1988 (Grove 1988) and in a second edition with two volumes and a new title in 2004 (Grove 2004). As the level of detail provided in this book is far beyond what we can present here, we refer the interested reader to this book and focus here only on some aspects of the book along with the new findings reported in the more recent literature.

\subsubsection{Length changes}

As described in Section 3, the most detailed knowledge we have on glacier fluctuations since the LIA is a result of direct measurements of length changes in the field with partly annual resolution for up to a few hundred glaciers globally (e.g. Zemp et al. 2015). Global overviews of the fluctuations can be found in (WGMS 2015, 2008) who include a regional analysis, in the study by (Leclercq et al. 2014) who include a detailed statistical analysis of the fluctuations and the source data, and in IPCC AR5 (Vaughan et al. 2013) presenting a more selective and generalized picture. Regional-scale analysis of the observed length changes since 1900 (or even earlier) are available for several regions such as for Norway by Andreassen et al. (2005), Italy (Citterio et al. 2007) or the Greater Himalaya (Bolch et al. 2012; Mayewski and Jeschke 1979). The measurements provide the following generalized insights:

- glaciers retreated from their LIA maximum position in all regions of the world;

- depending on their size, the terminus retreat is up to a few $\mathrm{km}$ for the largest glaciers;

- the general retreat was interrupted by intermediate phases of advance (at different times), in particular for more quickly responding medium-sized mountain glaciers;

- for larger glaciers the amplitude of the change is also larger (but exceptions exist);

- some regions have special glaciers, that retreat or advance also for non-climatic reasons (dynamic thinning of marine/lacustrine terminating or rapid advance of surging glaciers);

- these can retreat over much larger distances (ten's of $\mathrm{km}$ ) and advance much faster (in a few years) over distances of a few $\mathrm{km}$, i.e. the typical range of LIA fluctuations;

- in case glaciers are covered by thick debris, their retreat can be much slower than for clean glaciers, at least when the terminus is not calving into water; and

- differences in regional trends can be largely explained with different climatic conditions (e.g. increased winter precipitation), whereas local differences can be explained by the specific characteristics of individual glaciers (e.g. size, response time, hypsometry).

For some regions of the world, such as Greenland (Leclercq et al. 2012), Gangotri Glacier in the Himalaya (Bhambri et al. 2012), or selected outlet glaciers of the Patagonian Icefields and the Cordillera Darwin (Lopez et al. 2010), satellite data were used to add further points in time to the length change record of several individual glaciers. The latter study partly revealed dramatic retreats (up to $10 \mathrm{~km}$ from about 1980 to 2011) for several of larger glaciers (Nef, San Rafael, Uppsala, Jorge Montt, Marinelli), but they are all calving in pro-glacial lakes that likely enhanced their retreat. On the other hand, very high rates of glacier retreat $(4 \mathrm{~km}$ from 
1986 to 2011) and massive shrinkage of larger glaciers have also been documented for several land-terminating glaciers in Chile (Rivera et al. 2012) and northern Patagonia (Paul and Mölg 2014) using satellite data. In this region, the lakes that grow as glaciers retreat often cover the

\subsubsection{Area changes}

A large number of studies have reconstructed time-series of changes in glacier extents since the LIA (cf. Grove 2004). Whereas these studies generally confirm what is known about glacier fluctuations from length changes, their special advantage of also providing two dimensional information of past glacier extents has not yet been fully exploited, basically as they lack digital availability. Hence, our knowledge is limited to regions where LIA extents have also been derived from topographic maps. Detailed studies of glacier area changes since the LIA have been performed for individual glaciers in the Pyrenees (Cía et al. 2005), the French Alps (Marti et al. 2015), the Italian Alps (Carturan et al. 2014), the Drangajøkull ice cap in Iceland (Brynjólfsson et al. 2015), or the Caucasus (Solomina et al. 2016) and small samples of glaciers around Mt. Kenya (Hastenrath 2005), Jotunheimen in Norway (Baumann et al. 2009), the Pyrenees (González Trueba et al. 2008), the Bavarian Alps (Hagg et al. 2012) or the Windriver Range (DeVisser and Fountain 2015) using field surveys, historic topographic maps, aerial photography and also satellite images.

Samples over entire mountain ranges are available for Austria (Fischer et al. 2015), the Swiss Alps (Maisch et al. 2000) and western Italy (Lucchesi et al. 2014) (see 4.2.1 for results). Satellite data have been used to map LIA extents from trimlines on Baffin Island (Svoboda and Paul 2009), for local glaciers in parts of western Greenland (Citterio et al. 2009), for large parts of Patagonia (Davies and Glasser 2012), or for south-east Tibet (Loibl et al. 2014). The obtained values of area change are not directly comparable as time periods, climatic regimes, glacier characteristics and sample sizes differ, but most of them indicate an area loss of about 30 to $60 \%$ since their mapped 1850 maximum extent.

A most comprehensive and regionalized overview on glacier changes can be found in the GLIMS book (Kargel et al. 2014) along with detailed descriptions on the techniques applied in each region. Vaughan et al. (2013) is giving a more generalized overview of the derived area change rates (in per cent per year) from about 1940 to 2010. This overview study is sorted for the RGI regions and revealed the following main findings:

- in the mean over an entire study region, glaciers decreased in size everywhere

- several hundred glaciers melted completely

- relative area change rates are similar in most study regions, but there is also variability of the rates within a single RGI region

- most of the relative change rates varied between -0.05 and $-0.5 \%$ per year (1940-2010)

- several regions also showed higher rates ( -0.5 to $-1 \%$ per year), but for a more recent and shorter time period (1970s-2010)

- the largest shrinkage rates (-1 to $-2 \%$ per year) are found in the European Alps, the Low Latitudes and western Canada, the latter over a comparably short period of 15 years

- the majority of the studies with multi-temporal assessments show an increase in shrinkage rates for the more recent period (but several also have no trends or a slight decrease)

These averaged values confirm the results obtained from the more detailed investigations at individual glaciers, but their changes can be much higher or lower. Considering that relative area changes depend on glacier area (e.g. Paul et al. 2004; Bolch et al. 2010b; Gardent et al. 2014), area changes should always only be compared across entire mountain ranges or for 
glaciers of the same size class.

\subsection{Changes in the Alps}

\subsubsection{Length}

As mentioned above, the record of directly observed glacier length changes in the Alps is one of the longest on record and most comprehensive worldwide. More than 300 glaciers have been observed over a certain time period and several glaciers provide more or less (allowing gaps of up to 5 years) continuous time series since 1895 (Zemp et al. 2015). Zemp et al. (2008) provided a generalized Alpine-wide overview of length changes from 1850-2000 (along with area changes and mass changes from 1950 to 2000) and Citterio et al. (2007) presented a detailed analysis of length changes in the Italian Alps over the 1908 to 2000 period. These studies indicate stationary or advancing glaciers in the Alps around 1890 (only Zemp et al. 2008), in the 1930s and from the 1970s to 1980s as intermittent phases superimposed on a general trend of retreat (see Fig. 5). In general, mostly medium-sized and steep (mountain) glaciers with comparably short response times took part in the advance phases, whereas larger and flat (valley) glaciers with long response times continued their general retreat (Fig. 5). For the 1970 s advance phase also differences in hypsometry played a role to explain the partly very different responses (strong advance vs. continuous retreat) of neighbouring glaciers (Kuhn et al. 1985).

Cumulative retreats reached 1-2.5 km for the largest glaciers (e.g. Great Aletsch, Gorner, Pasterze) and advances reached several hundred meters for some strongly reacting mountain glaciers such as Trient in the Mt. Blanc region and Kesselwand in the Oetztaler Alps. Whereas the specific reasons for the advances of individual glaciers are complex and depending on many factors, atmospheric conditions acting on a mountain range scale play a role as well. Lüthi and Bauder (2010) used the dense time-series of length change measurements in Switzerland for a reconstruction of the corresponding variability in the ELA with a macroscopic glacier flow model. They found that a single time series of ELA fluctuations could explain the observed terminus fluctuations after 1850 but not the variability during the LIA. In general, the advances of the 1930s and 1970s to 1980s seem to follow several years of balanced or positive mass budgets (see 4.2.3) with a decade or so, compliant with the typical response times of steep mountain glaciers (Haeberli and Hoelzle 1995).

\subsubsection{Area}

Reconstruction of LIA maximum glacier extents in the Swiss Alps is largely based on comparably accurate topographic maps that have been derived from land surveys in the period 1845 to 1865 and are known as the Dufourmap (swisstopo.ch). Together with field surveys and high-resolution aerial photography (for confirmation of moraines), Maisch et al. (2000) used this information for a precise reconstruction of maximum LIA extents for all Swiss glaciers. This dataset was at first only prepared in analogue form and thus analysed using cartographic and planimetric techniques (Maisch 1992). However, later glacier extents were also digitized together with extents from the 1973 Swiss Glacier Inventory (Paul 2004) and analysed digitally in regard to glacier area changes (Paul et al. 2004). More recently, LIA extents were also digitized and analysed for Austria (Fischer et al. 2015) and western Italy (Lucchesi et al. 2014).

The above studies reveal an area loss of about 30 to $40 \%$ (or $0.3 \% / \mathrm{a}$ ) from 1850 to the $1970 \mathrm{~s}$, a further $15-20 \%$ (or $0.6 \% /$ a) from 1973 until 2000 (that mostly occurred after 1985), a further $10-15 \%$ from 2000 to 2010 (or $1.2 \% / \mathrm{a}$ ), and a total of $50-60 \%$ for the entire period (Zemp et al. 2008; Fischer et al. 2015; Maisch et al. 2000). The extrapolation by Zemp et al. (2008) for the entire Alps gives a total area change from $4400 \mathrm{~km}^{2}$ in 1850 to $2900 \mathrm{~km}^{2}$ in the $1970 \mathrm{~s}$ and a further reduction to $2200 \mathrm{~km}^{2}$ by 2000 . Hence, an area of about $2200 \mathrm{~km}^{2}$ has 
transformed from being glacier covered to glacier forefield in 150 years. Gardent et al. (2014) compiled from the body of literature relative area change rates for various regions in the Alps and found rates of about $-1.5 \%$ per year for the 1990-2010 period and -2 and $-3 \%$ for the most yet in balance with current climatic conditions and that non-climatic feedback effects due to surface lowering and disintegration might play a role (e.g. Carturan et al. 2013b).

\subsubsection{Mass balance}

For the Alps we have also a rather good overview on the temporal development of mass balances, as several long-term time-series are available (e.g. WGMS 2015). Huss et al. (2010) extrapolated annual mass balances of 30 Swiss glaciers back to 1900 using climate data, direct measurements and the available geodetic surveys for calibration. This reconstruction shows a period of mass gain from 1910 to 1920 and 1970 to 1980 , rather balanced conditions between 1950 and 1970 and periods of strong mass loss from 1940 to 1950 , and since 1985 . However, strong inter-annual fluctuations were observed in each of the periods after 1950 (Zemp et al. 2015), indicating that some longer term averaging (5-10 years) is required for trend detection. When analysing 10-year means, mean annual mass budgets in the Alps are getting increasingly negative since 1980 , about $-0.33 \mathrm{~m}$ w.e. for $1980-1989$, $-0.81 \mathrm{~m}$ w.e. for 1990-1999 and -1.25 m w.e. for 2000-2009. This increasingly negative trend reveals that glacier extents cannot adjust quickly enough and ablation areas get increasingly larger (seasonal mass balance measurements indicate that there is no trend in winter precipitation) combined with continued surface lowering. Under current climate conditions this process will continue for decades, in particular for the larger glaciers with long response times. With current AARs of about $30 \%$, total areas have to be diminished by a further $50 \%$ to get again an $\mathrm{AAR}_{0}$ of 0.6 and stable glacier extents (Zemp et al. 2015; Dyurgerov et al. 2009; Carturan et al. 2013a).

\section{Discussion and future challenges}

\subsection{Length and area changes}

Although glacier area and length are correlated, changes in the respective parameters provide complimentary information. This also applies to their methods of determination (often fieldbased for length vs. remote sensing for area), their spatial sampling (individual vs. all glaciers in a mountain range), period of available observations (centuries vs. decades), and temporal resolution (annual vs. decadal). When combined, a most complete picture on climate change impacts on glaciers and our environment can be derived (e.g. Vaughan et al. 2013). However, it has to be noted that area changes are per se not really a good climate indicator, as the relation with climate change is complex and depending on several other factors (e.g. ice thickness distribution, hypsometry, debris cover). This is different for length changes that can be well reconstructed from climate data using glacier flow models and vice versa (e.g. Jouvet et al. 2009).

However, there is also some climatic information in area changes: They can be globally compared, show the potential variability among and within regions (Vaughan et al. 2013), or help in interpreting current trends (see 4.2.1) and recognize potential accelerations (e.g. Paul et al. 2004). Area change rates are useful to extrapolate glacier inventories to other time periods, for example to close observational gaps (Zemp et al. 2008) or initialisation of climate models for a given time (Kotlarski et al. 2010). Once outlines from different points in time (e.g. LIA and today) are digitally available, numerous additional calculations can be performed, for example the related volume changes and sea level contribution (Glasser et al. 2011), the impacts of geometric changes on measured and modelled mass budgets (Paul 2010; Huss et al. 2012), length changes from digital intersection of extents with central flowlines, changes in mean 
elevation as a proxy for ELA and thus former climatic conditions (Wolken et al. 2008), and calibration of models simulating past and future glacier extents (Marzeion et al. 2012; Huss and Hock 2015). Hence, despite their limited use as a direct indicator of climate change, multi-temporal glacier extents are very useful for numerous calculations related to climate change and a globally more complete dataset of digitally available extents (back to the LIA) is highly desirable (Marzeion et al. 2017).

\subsection{Glacier forefields}

Owing to the committed future area loss and the very likely further increasing global temperatures glacier forefields will further grow. The new terrain will not only consist of unconsolidated debris, but also of bare rock and lakes. On the positive site, it will in some cases (at elevations below the tree line) only take a few decades before plants stabilize the debris (Burga 1999) and new lakes might develop and get touristic attention and value. However, shrinking glaciers and expanding forefields also have some down sides. Apart from the increasing potential for debris flows due to the reduced retention of rain by glaciers and the increasing area of steep lateral moraines and bare rocks, there are several further likely negative impacts. For example, access to mountain huts might get difficult when glaciers shrink and the terrain follows or when the glacier is replaced by a lake or a steep moraine wall (Ritter et al. 2012).

Pro-glacial lakes might also be a growing hazard as the dams holding them back can burst creating so-called glacier lake outburst floods (GLOFs) (Richardson and Reynolds 2000; Bolch et al. 2011). Such bursts can be triggered by mass movements (rock fall), which might occur as a result of reduced buttressing by the now missing glacier (Oppikofer et al. 2008; Kos et al. 2016), from steep moraine walls and thawing permafrost above such a lake (Frey et al. 2010, Haeberli et al. in press). The GLOFs can travel downstream for dozens of kilometres, thus reaching and potentially damaging human infrastructure or settlements (e.g. Clague and Evans 2000; Huggel et al. 2003). On a positive note, these lakes can be automatically mapped from satellite images and their extents are thus digitally available (e.g. Bolch et al. 2008; Gardelle et al. 2011; ICIMOD 2011). In the case they are classified as dangerous, they are sometimes also monitored from the ground so that early warnings can be released (e.g. Carey et al. 2012). A special problem is that in many regions glacier shrinkage is so fast, that new lakes are constantly formed and a frequent reassessment is required. Such lakes might also have a potential to be used for hydropower purposes (Haeberli et al. 2016a), or they can build an important sediment trap (at least for some years) that keep the sediment away from hydro-power dams downstream (Haeberli et al. 2012). In short, growing glacier forefields can influence the sediment balance in both ways, strongly increasing it (no lake) or reducing it.

\subsection{Future challenges}

Current rates of area loss are in some regions (Alps, Andes) an order of magnitude higher than in the decades following the LIA maximum extent. Current 2D/3D glacier flow models start to correctly model also changes in glacier area on a regional scale (Huss and Hock 2015; Clarke et al. 2015), but this is highly challenged due to missing information about the bedrock or ice thickness distribution as well as missing multi-temporal validation data. However, for some well-studied glaciers such as Rhone or Great Aletsch in Switzerland modeling results (for past extents) are in good agreement with observations (e.g. Jouvet et al. 2011). Not yet included are effects on the radiation balance (replacing bright glacier ice with dark gravel or rock) that might cause additional heating in case glaciers shrink (Carturan et al. 2013a). This would enhance glacier melt, might change snow fall to rain and increase thawing of permafrost higher up (Gobiet et al. 2014). The resulting overall destabilisation of the environment towards a state of imbalance will challenge computation of related effects and cause more severe and unforeseen impacts of extreme events due to missing historic knowledge and nonlinear effects in cascading response systems. 


\section{Summary}

We described basic principles of glacier response to climate change, glacier changes as measured in the field and from space, and presented an overview of glacier fluctuations around the world with a particular focus on the Alps. As not all details could be included in this overview, we focused on key references under each topic and the more general relations and results. With the on-going glacier retreat glacier forefields are further growing. They are continuously changing on time-scales of minutes (flooding) to millennia and record past glacier fluctuations. Detailed investigations about this very dynamic environment exist only locally and a quantification of the new land that has been exposed after glacier retreat is only regionally available, as the digital mapping of LIA extents started only recently. Nevertheless, simplified schemes allow reconstruction of the regional climatic history using ELA depressions derived from the topographic analysis of former glacier extents. For the time after the LIA the observed glacier retreat of a few kilometre for the largest glaciers is in good agreement with the required increase in temperature of about one degree since the LIA. As all glaciers are different, such numbers show substantial glacier-specific variability, but consideration of such differences provides consistent results. The pro-glacial lakes that are currently growing in many mountain regions of the world as glaciers retreat, are both a source of hazards (GLOFs) and a landscape element with touristic and economic (hydro-power) potential. It remains to be seen whether lakes as a hazard source or their touristic and economic potential will prevail.

\section{Acknowledgements}

This study has been funded by the ESA project Glaciers_cci (4000109873/14/I-NB). We would like to thank an anonymous reviewer and S. Nussbaumer for their helpful comments to improve the paper. 


\section{References}

Andreassen LM, Elvehøy H, Kjøllmoen B, Engeset RV, Haakensen N (2005) Glacier mass balance and length variations in Norway. Ann Glaciol 42:317-325

Bahr DB, Dyurgerov M, Meier MF (2009) Sea-level rise from glaciers and ice caps: A lower bound. Geophys Res Lett 36(3):L03501. doi: 10.1029/2008GL036309

Barandun M, Huss M, Sold L, Farinotti D, Asisov E, Salzmann N, Usubaliev R, Merkushkin A, Hoelzle M (2015) Re-analysis of seasonal mass balance at Abramov glacier 19682014. J Glaciol 61(230):1103-1117

Baroni C, Orombelli G (1996) The Alpine "iceman" and holocene climatic change. Quaternary Res 46(1):78-83

Baumann S, Winkler S, Andreassen LM (2009) Mapping glaciers in Jotunheimen, SouthNorway, during the "Little Ice Age" maximum. Cryosphere 3(2):231-243

Beniston M (2006) Mountain weather and climate: A general overview and a focus on climatic change in the Alps. Hydrobiologia 562:3-16

Benn DI, Lehmkuhl F (2000) Mass balance and equilibrium-line altitudes of glaciers in highmountain environments. Quatern Int (65/66):15-29

Bhambri R, Bolch T, Chaujar RK (2012) Frontal recession of Gangotri Glacier, Garhwal Himalayas, from 1965-2006, measured through high resolution remote sensing data. Curr Sci India 102(3):489-494

Böhm A, Auer I, Brunetti M, Maugueri M, Nanni T, Schöner W (2001) Regional temperature variability in the European Alps: 1760-1998 from homogenized instrumental time series. Int J Climatol 21(14):1779-1801

Bolch T, Kamp U (2006) Glacier Mapping in High Mountains using DEMs, Landsat and ASTER Data. Grazer Schriften der Geographie und Raumforschung 41 (Proceedings of the 8th Int. Symp. on High Mountain Remote Sensing Cartography, 20-27 March 2005, La Paz, Bolivia):13-24

Bolch T, Chrsitiansen, H (2014) Large scale settings: The physiography of the cryosphere. In: Haeberli, W. and Whiteman, C. (eds.): Snow and Ice-Related Hazards, Risks and Disasters. In: Haeberli W and Whiteman C (eds.): Snow and Ice-Related Hazards, Risks and Disasters. Elsevier: 201-217

Bolch T, Buchroithner MF, Peters J, Baessler M, Bajracharya SR (2008) Identification of glacier motion and potentially dangerous glacier lakes at Mt. Everest area/Nepal using spaceborne imagery. Nat Hazards Earth Syst Sci 8(6):1329-1340

Bolch T, Menounos B, Wheate RD (2010a) Landsat-based inventory of glaciers in western Canada, 1985 - 2005. Remote Sens Environ 114(1):127-137

Bolch T, Yao T, Kang S, Buchroithner MF, Scherer D, Maussion F, Huintjes E, Schneider C (2010b) A glacier inventory for the western Nyainqentanglha Range and Nam Co Basin, Tibet, and glacier changes 1976-2009. Cryosphere 4:419-433

Bolch T, Peters J, Pradhan B, Yegorov AB, Buchroithner MF, Blagoveshchenskiy VP (2011) Identification of potentially dangerous glacial lakes in the northern Tien Shan. Nat Hazards 59(3):1691-1714

Bolch T, Kulkarni A, Kääb A, Huggel C, Paul F, Cogley JG, Frey H, Kargel JS, Fujita K, Scheel M, Bajracharya S, Stoffel M (2012) The state and fate of Himalayan glaciers. Science 336(6079):310-314

Braithwaite RJ, Raper S (2009) Estimating equilibrium-line altitude (ELA) from glacier inventory data. Ann. Glaciol. 50(53):127-132

Brynjólfsson S, Schomacker A, Guðmundsdóttir ER, Ingólfsson Ó (2015) A 300-year surge history of the Drangajökull ice cap, northwest Iceland, and its maximum during the 'Little Ice Age'. Holocene 25(7):1076-1092

Burga C (1999) Vegetation development on the glacier forefield Morteratsch (Switzerland). Appl Veg Sci 2:17-24 
Carey M, Huggel C, Bury J, Portocarrero C, Haeberli W (2012) An integrated socio-

653

654

655

656

657

658

659

660

661

662

663

664

665

666

667

668

669

670

671

672

673

674

675

676

677

678

679

680

681

682

683

684

685

686

687

688

689

690

691

692

693

694

695

696

697

698

699

700

701 environmental framework for glacier hazard management and climate change adaptation: lessons from Lake 513, Cordillera Blanca, Peru. Climatic Change 112(3):733-767

Carturan L, Baroni C, Becker M, Bellin A, Cainelli O, Carton A, Casarotto C, Dalla Fontana G, Godio A, Martinelli T, Salvatore MC, Seppi R (2013a) Decay of a long-term monitored glacier: Careser Glacier (Ortles-Cevedale, European Alps). Cryosphere 7(6):1819_ 1838

Carturan L, Filippi R, Seppi R, Gabrielli P, Notarnicola C, Bertoldi L, Paul F, Rastner P, Cazorzi F, Dinale R, Dalla Fontana G (2013b) Area and volume loss of the glaciers in the Ortles-Cevedale group (Eastern Italian Alps): controls and imbalance of the remaining glaciers. Cryosphere 7(5):1339-1359

Carturan L, Baroni C, Carton A, Cazorzi F, Fontana GD, Delpero C, Salvatore MC, Seppi R, Zanoner T (2014) Reconstructing Fluctuations of La Mare Glacier (Eastern Italian Alps) in the Late Holocene: New Evidence for a Little Ice Age Maximum Around 1600 AD. Geogr Ann A 96(3):287-306

Chinn T, Winkler S, Salinger MJ, Haakensen N (2005) Recent glacier advances in Norway and New Zealand: a comparison of their glaciological and meteorological causes. Geogr Ann A 87(1):141-157

Cía JC, Andrés AJ, Sánchez MS, Novau JC, Moreno JL (2005) Responses to climatic changes since the Little Ice Age on Maladeta Glacier (Central Pyrenees). Geomorphology 68(34):167-182

Citterio M, Diolaiuti G, Smiraglia C, D'Agata C, Carnielli T, Stella G, Siletto GB (2007) The fluctuations of Italian glaciers during the last century: a contribution to the knowledge about alpine glacier changes. Geogr Ann A 89(3):167-184

Citterio M, Paul F, Ahlstrøm AP, Jepsen HF, Weidick A (2009) Remote sensing of glacier change in West Greenland: accounting for the occurrence of surge-type glaciers. Ann Glaciol 50(53):70-80

Clague JJ, Evans SG (2000) A review of catastrophic drainage of moraine-dammed lakes in British Columbia. Quaternary Sci Rev 19:1763-1783

Clarke GKC, Jarosch AH, Anslow FS, Radic V, Menounos B (2015) Projected deglaciation of western Canada in the twenty-first century. Nature Geosci 8(5):372-377

Davies BJ, Glasser NF (2012) Accelerating shrinkage of Patagonian glaciers from the Little Ice Age (AD 1870) to 2011. J Glaciol 58(212):1063-1084

DeVisser MH, Fountain AG (2015) A century of glacier change in the Wind River Range, WY. Geomorphology 232:103-116

Dyurgerov M, Meier MF, Bahr DB (2009) A new index of glacier area change: a tool for glacier monitoring. J Glaciol 55(192):710-716

Egli M, Wernli M, Kneisel C, Biegger S, Haeberli W (2006) Melting glaciers and soil development in the proglacial area Morteratsch (Swiss Alps): II. Modeling the present and future soil state. Arct Antarct Alp Res 38(4):510-521

Fischer A, Seiser B, Stocker Waldhuber M, Mitterer C, Abermann J (2015) Tracing glacier changes in Austria from the Little Ice Age to the present using a lidar-based highresolution glacier inventory in Austria. Cryosphere 9:753-766

Frey H, Haeberli W, Linsbauer A, Huggel C, Paul F (2010) A multi-level strategy for anticipating future glacier lake formation and associated hazard potentials. Nat Hazards Earth Syst Sci 10:339-352

Gardelle J, Arnaud Y, Berthier E (2011) Contrasted evolution of glacial lakes along the Hindu Kush Himalaya mountain range between 1990 and 2009. Global Planet Change 75:47-55

Gardent M, Rabatel A, Dedieu J, Deline P (2014) Multitemporal glacier inventory of the French Alps from the late 1960s to the late 2000s. Global Planet Change 120:24-37 
Glasser NF, Harrison S, Jansson KN, Anderson K, Cowley A (2011) Global sea-level contribution from the Patagonian Icefields since the Little Ice Age maximum. Nature Geosci 4(11):303-307

Gobiet A, Kotlarski S, Beniston M, Heinrich G, Rajczak J, Stoffel M (2014) 21st century climate change in the European Alps-A review. Science of The Total Environment 493:1138-1151. doi: 10.1016/j.scitotenv.2013.07.050

González Trueba JJ, Moreno RM, Martínez de Pisón E, Serrano E (2008) 'Little Ice Age' glaciation and current glaciers in the Iberian Peninsula. Holocene 18(4):551-568

Grove JM (1988) The Little Ice Age. Methuen, London and New York

Grove JM (2004) Little Ice Ages: Ancient and Modern: 2nd edition. Routledge, London

Haeberli W, Hoelzle M (1995) Application of inventory data for estimating characteristics of and regional climate-change effects on mountain glaciers: a pilot study with the European Alps. Ann Glaciol 21:206-212

Haeberli W, Schleiss A, Linsbauer A, Künzler M, Bütler M (2012) Gletscherschwund und neue Seen in den Schweizer Alpen. Wasser Energie Luft 104(2):93-102

Haeberli W, Buetler M, Huggel C, Friedli TL, Schaub Y, Schleiss AJ (2016a) New lakes in deglaciating high-mountain regions - opportunities and risks. Climatic Change 139(2):201-214

Haeberli W, Linsbauer A, Cochachin A, Salazar C, Fischer UH (2016b) On the morphological characteristics of overdeepenings in high-mountain glacier beds. Earth Surf Process Landforms 41(13):1980-1990

Haeberli W, Schaub Y, Huggel C (in press) Increasing risks related to landslides from degrading permafrost into new lakes in de-glaciating mountain ranges. Geomorphology. doi:10.1016/j.geomorph.2016.02.009

Hagg W, Mayer C, Mayr E, Heilig A (2012) Climate and glacier fluctuations in the Bavarian Alps in the past 120 years. Erdkunde 66(2):121-142

Hastenrath S (2005) The glaciers of MountKenya 1899-2004. Erdkunde 59(2):120-125

Heckmann T, McColl S, Morche D (2016) Retreating ice: research in pro-glacial areas matters. Earth Surf Process Landforms 41(2):271-276

Holzhauser H, Magny M, Zumbuühl HJ (2005) Glacier and lake-level variations in westcentral Europe over the last 3500 years. Holocene 15(6):789-801

Hormes A, Müller BU, Schlüchter C (2001) The Alps with little ice: evidence for eight Holocene phases of reduced glacier extent in the Central Swiss Alps. Holocene 11(3):255-265

Huggel C, Kääb A, Haeberli W, Krummenacher B (2003) Regional-scale GIS-models for assessment of hazards from glacier lake outbursts: evaluation and application in the Swiss Alps. Nat Hazards Earth Syst Sci 3:647-662

Huss M, Hock R (2015) A new model for global glacier change and sea-level rise. Front Earth Sci 3:54. doi: 10.3389/feart.2015.00054

Huss M, Hock R, Bauder A, Funk M (2010) 100-year mass changes in the Swiss Alps linked to the Atlantic Multidecadal Oscillation. Geophys Res Lett 37(10):L10501. doi: 10.1029/2010GL042616

Huss M, Hock R, Bauder A, Funk M (2012) Conventional versus reference-surface mass balance. J Glaciol 58(208):278-286

ICIMOD (2011) Glacial lakes and glacial lake outburst floods in Nepal. Kathmandu.

Ivy-Ochs S, Kerschner H, Maisch M, Christl M, Kubik PW, Schlüchter C (2009) Latest Pleistocene and Holocene glacier variations in the European Alps. Holocene and Latest Pleistocene Alpine Glacier Fluctuations: A Global Perspective. Quaternary Sci Rev 28(2122):2137-2149

Joerin UE, Stocker TF, Schlüchter C (2006) Multicentury glacier fluctuations in the Swiss Alps during the Holocene. Holocene 16(5):697-704 
Joerin UE, Nicolussi K, Fischer A, Stocker TF, Schlüchter C (2008) Holocene optimum events inferred from subglacial sediments at Tschierva Glacier, Eastern Swiss Alps. Quaternary Sci Rev 27(3-4):337-350

Jomelli V, Favier V, Rabatel A, Brunstein D, Hoffmann G, Francou B (2009) Fluctuations of glaciers in the tropical Andes over the last millennium and palaeoclimatic implications: A review. Palaeogeogr Palaeocl 281(3-4):269-282

Jouvet G, Huss M, Blatter H, Picasso M, Rappaz J (2009) Numerical simulation of Rhonegletscher from 1874 to 2100. J Comput Phys 228(17):6426-6439

Jouvet G, Huss M, Funk M, Blatter H (2011) Modelling the retreat of Grosser Aletschgletscher, Switzerland, in a changing climate. J Glaciol 57(206):1033-1045

Kargel JS, Leonard GJ, Bishop MP, Kääb A, Raup BH (eds) (2014) Global Land Ice Measurements from Space. Springer Praxis Books. Springer Berlin Heidelberg

Kerschner H, Ivy-Ochs S (2008) Palaeoclimate from glaciers: Examples from the Eastern Alps during the Alpine Lateglacial and early Holocene. Historical and Holocene glacier climate variations. Global Planet Change 60(1-2):58-71

Koch J, Clague JJ, Osborn G (2007) Glacier fluctuations during the last millennium in Garibaldi Provincial Park, southern Coast Mountains, British Columbia. Can J Earth Sci 44:1215-1233

Koch J, Clague JJ, Osborn G (2014) Alpine glaciers and permanent ice and snow patches in western Canada approach their smallest sizes since the mid-Holocene, consistent with global trends. Holocene 24(12):1639-1648

Kos A, Amann F, Strozzi T, Delaloye R, von Ruette J, Springman S (2016) Contemporary glacier retreat triggers a rapid landslide response, Great Aletsch Glacier, Switzerland. Geophys Res Lett 43:12,466-12,474. doi:10.1002/ 2016GL071708

Kotlarski S, Jacob D, Podzun R, Paul F (2010) Representing glaciers in a Regional Climate Model. Clim Dyn 34(1):27-46

Kuhn M (1981) Climate and glaciers. IAHS Publication(131):3-20

Kuhn M, Markl G, Kaser G, Nickus U, Obleitner, F., Schneider, H. (1985) Fluctuations of climate and mass balance:different responses of two adjacent glaciers. Z Gletscherkd Glazialgeol 21:409-416

Leclercq PW, Weidick A, Paul F, Bolch T, Citterio M, Oerlemans J (2012) Historical glacier length changes in West Greenland. Cryosphere 6:1339-1343

Leclercq PW, Oerlemans J, Basagic HJ, Bushueva I, Cook AJ, Le Bris R (2014) A data set of worldwide glacier length fluctuations. Cryosphere 8(2):659-672

Linsbauer A, Paul F, Haeberli W (2012) Modeling glacier thickness distribution and bed topography over entire mountain ranges with GlabTop: Application of a fast and robust approach. J. Geophys. Res. 117:F03007. doi:10.1029/2011JF002313

Loibl D, Lehmkuhl F, Grießinger J (2014) Reconstructing glacier retreat since the Little Ice Age in SE Tibet by glacier mapping and equilibrium line altitude calculation. Geomorphology 214:22-39

Lopez P, Chevallier P, Favier V, Pouyaud B, Ordenes F, Oerlemans J (2010) A regional view of fluctuations in glacier length in southern South America. Global Planet Change 71(12):85-108

Loriaux T, Casassa G (2013) Evolution of glacial lakes from the Northern Patagonian Icefield and terrestrial water storage in a sea-level rise context. Global Planet. Change, 102, 33-40

Lucchesi S, Fioraso G, Bertotto S, Chiarle M (2014) Little Ice Age and contemporary glacier extent in the Western and South-Western Piedmont Alps (North-Western Italy). J Maps $10(3): 409-423$

Luckman BH (2000) The Little Ice Age in the Canadian Rockies. Geomorphology 32(3):357384.

Lüthi M, Bauder A (2010) Analysis of Alpine glacier length change records with a macroscopic glacier model. Geographica Helvetica 2:92-102 
Maisch M (1992) Die Gletscher Graubündens. Rekonstruktion und Auswertung der Gletscher und deren Veränderung seit dem Hochstand von 1850 im Gebiet der östlichen Schweizer Alpen (Bündnerland und angrenzende Regionen). Teil A: Grundlagen, Analysen, Ergebnisse; Teil B: Verzeichnisse, Datenkataloge, Gletscherkarten. Physische Geographie Zurich

Maisch M, Wipf A, Denneler B, Battaglia J, Benz C (2000) Die Gletscher der Schweizer Alpen - Gletscherhochstand 1850 - Aktuelle Vergletscherung - Gletscherschwundszenarien, Schlussbericht NFP 31, 2nd edn. Hochschulverlag ETH Zürich

Marti R, Gascoin S, Houet T, Ribière O, Laffly D, Condom T, Monnier S, Schmutz M, Camerlynck C, Tihay JP, Soubeyroux JM, René P (2015) Evolution of Ossoue Glacier (French Pyrenees) since the end of the Little Ice Age. Cryosphere 9(5):1773-1795

Marzeion B, Jarosch AH, Hofer M (2012) Past and future sea-level change from the surface mass balance of glaciers. Cryosphere 6(6):1295-1322

Marzeion B, Champollion N, Haeberli W, Langley K, Leclercq P, Paul F (2017) Observation of glacier mass changes on the global scale and its contribution to sea level change. Surv Geophys 38(1): 105-130

Masiokas MH, Luckman BH, Villalba R, Delgado S, Skvarca P, Ripalta A (2009a) Little Ice Age fluctuations of small glaciers in the Monte Fitz Roy and Lago del Desierto areas, south Patagonian Andes, Argentina. Palaeogeogr Palaeocl 281(3-4):351-362

Masiokas MH, Rivera A, Espizua LE, Villalba R, Delgado S, Aravena JC (2009b) Glacier fluctuations in extratropical South America during the past 1000 years. Palaeogeogr Palaeocl 281(3-4):242-268

Matthews JA, Briffa KR (2005) The 'Little Ice Age': re-evaluation of an evolving concept. Geogr Ann A 87(1):17-36

Mayewski PA, Jeschke PA (1979) Himalayan and Trans-Himalayan Glacier Fluctuations Since AD 1812. Arctic Alpine Res 11(3):267-287

Narama C, Kääb A, Duishonakunov M, Abdrakhmatov K (2010) Spatial variability of recent glacier area changes in the Tien Shan Mountains, Central Asia, using Corona (1970), Landsat (2000), and ALOS (2007) satellite data. Global Planet Change 71(1-2):42-54

Nesje A, Bakke J, Dahl SO, Lie Ø, Matthews JA (2008a) Norwegian mountain glaciers in the past, present and future. Historical and Holocene glacier - climate variations. Global Planet Change 60(1-2):10-27

Nesje A, Dahl SO, Thun T, Nordli Ø (2008b) The 'Little Ice Age' glacial expansion in western Scandinavia: summer temperature or winter precipitation? Clim Dyn 30(7):789-801

Nussbaumer SU, Zumbühl HJ, Steiner D (2007) Fluctuations of the Mer de Glace (Mont Blanc area, France) AD 1500-2050. Part I: The history of the Mer de Glace AD 15702003 according to pictorial and written documents. Z Gletscherkunde Glazialgeol, 40: 5140.

Nussbaumer SU, Nesje A, Zumbühl HJ (2011a) Historical glacier fluctuations of Jostedalsbreen and Folgefonna (southern Norway) reassessed by new pictorial and written evidence. Holocene 21(3):455-471

Nussbaumer SU, Steinhilber F, Trachsel M, Breitenmoser P, Beer J, Blass A, Grosjean M, Hafner A, Holzhauser H, Wanner H, Zumbühl HJ (2011b) Alpine climate during the Holocene: a comparison between records of glaciers, lake sediments and solar activity. J Quat Sci 26(7):703-713

Oerlemans J (2001) Glaciers and climate change. Balkema Lisse

Oerlemans J (2005) Extracting a climate signal from 169 glacier records. Science 308:675677

Oppikofer T, Jaboyedoff M, Keusen H (2008) Collapse at the eastern Eiger flank in the Swiss Alps. Nature Geosci 1(8):531-535

Paul F (2002) Changes in glacier area in Tyrol, Austria, between 1969 and 1992 derived from Landsat 5 TM and Austrian Glacier Inventory data. Int J Remote Sens 23(4):787-799 
Paul F (2004) The new Swiss glacier inventory 2000 - Application of remote sensing and GIS. Dissertation, Physical Geography, University of Zurich Zurich

Paul F (2010) The influence of changes in glacier extent and surface elevation on modeled mass balance. Cryosphere 4(4):569-581

Paul F (2015) Kartierung von Gletschern mit Satellitendaten und das globale Gletscherinventar. In: Lozán JL, Grass1 H, Kasang D, Notz D Escher-Vetter H (Hrsg.): Warnsignal Klima: Das Eis der Erde (Kap. 4.1), 103-110

Paul F, Kääb A (2005) Perspectives on the production of a glacier inventory from multispectral satellite data in Arctic Canada: Cumberland Peninsula, Baffin Island. Ann Glaciol 42:59-66

Paul F, Haeberli W (2008) Spatial variability of glacier elevation changes in the Swiss Alps obtained from two digital elevation models. Geophys Res Lett 35:L21502. doi:10.1029/2008GL034718

Paul F, Mölg N (2014) Hasty retreat of glaciers in northern Patagonia from 1985 to 2011. J. Glaciol. 60(224):1033-1043

Paul F, Kääb A, Maisch M, Kellenberger T, Haeberli W (2004) Rapid disintegration of A1pine glaciers observed with satellite data. Geophys. Res. Lett 31(21):L21402. doi:10.1029/2004GL020816

Paul F, Maisch M, Rothenbüler C, Hoelzle M, Haeberli W (2007) Calculation and visualisation of future glacier extent in the Swiss Alps by means of hypsographic modelling. Global Planet Change 55(4):343-357

Pelto MS (2010) Forecasting temperate alpine glacier survival from accumulation zone observations. Cryosphere 4(1):67-75

Pfeffer W, Arendt AA, Bliss A, Bolch T, Cogley JG, Gardner AS, Hagen J, Hock R, Kaser G, Kienholz C, Miles ES, Moholdt G, Mölg N, Paul F, Radić V, Rastner P, Raup BH, Rich J, Sharp MJatRC (2014) The Randolph Glacier Inventory: a globally complete inventory of glaciers. J Glaciol 60(221):537-552

Porter SC (1975) Equilibrium-line altitudes of late Quaternary glaciers in the Southern Alps, New Zealand. Quaternary Res 5(1):27-47

Rabatel A, Dedieu J, Vincent C (2005) Using remote-sensing data to determine equilibriumline altitude and mass-balance time series: validation on three French glaciers. J Glaciol 51(175):539-546

Rabatel A, Francou B, Jomelli V, Naveau P, Grancher D (2008) A chronology of the Little Ice Age in the tropical Andes of Bolivia $\left(16^{\circ} \mathrm{S}\right)$ and its implications for climate reconstruction. Quaternary Res 70(2):198-212

Rabatel A, Francou B, Soruco A, Gomez J, Cáceres B, Ceballos JL, Basantes R, Vuille M, Sicart J, Huggel C, Scheel M, Lejeune Y, Arnaud Y, Collet M, Condom T, Consoli G, Favier V, Jomelli V, Galarraga R, Ginot P, Maisincho L, Mendoza J, Ménégoz M, Ramirez E, Ribstein P, Suarez W, Villacis M, Wagnon P (2013) Current state of glaciers in the tropical Andes: a multi-century perspective on glacier evolution and climate change. Cryosphere 7(1):81-102

Radić V, Hock R (2011) Regionally differentiated contribution of mountain glaciers and ice caps to future sea-level rise. Nature Geosci. 4(2):91-94

Reid PC, Hari RE, Beaugrand G, Livingstone DM, Marty C, Straile D, Barichivich J, Goberville E, Adrian R, Aono Y, Brown R, Foster J, Groisman P, Hélaouët P, Hsu H, Kirby R, Knight J, Kraberg A, Li J, Lo T, Myneni RB, North RP, Pounds JA, Sparks T, Stübi R, Tian Y, Wiltshire KH, Xiao D, Zhu Z (2016) Global impacts of the 1980s regime shift. Glob Change Biol 22(2):682-703

Richardson S, Reynolds J (2000) An overview of glacial hazards in the Himalayas. Quatern Int 65/66(1):31-47

Ritter F, Fiebig M, Muhar A (2012) Impacts of Global Warming on Mountaineering: A Classification of Phenomena Affecting the Alpine Trail Network. Mt Res Dev 32(1):4-15 
Rivera A, Bown F, Carrión D, Zenteno P (2012) Glacier responses to recent volcanic activity in Southern Chile. Environ Res Lett 7(1):14036. doi:10.1088/1748-9326/7/1/014036

Röthlisberger F (1986) 10000 Jahre Gletschergeschichte der Erde. Sauerländer, Aarau

Seltzer GO (1994) Climatic interpretation of alpine snowline variations on millennial time scales. Quaternary Res 41(2):154-159

Solomina ON, Bradley RS, Hodgson DA, Ivy-Ochs S, Jomelli V, Mackintosh AN, Nesje A, Owen LA, Wanner H, Wiles GC, Young NE (2015) Holocene glacier fluctuations. Quaternary Sci Rev 111(0):9-34

Solomina O, Bushueva I, Dolgova E, Jomelli V, Alexandrin M, Mikhalenko V, Matskovsky V (2016) Glacier variations in the Northern Caucasus compared to climatic reconstructions over the past millennium. Global Planet Change 140:28-58.

Svoboda F, Paul F (2009) A new glacier inventory on southern Baffin Island, Canada, from ASTER data: I. Applied methods, challenges and solutions. Ann Glaciol 50(53):11-21

UNEP (2007) Global outlook for ice and snow. UNEP/GRID-Arendal Norway

Vaughan DG, Comiso JC, Allison I, Carrasco J, Kaser G, Kwok R, Mote P, Murray T, Paul F, Ren J, Rignot E, Solomina O, Steffen K, Zhang T (2013) Observations: Cryosphere. In: Stocker T, Qin D, Plattner G, Tignor M, Allen S, Boschung J, Nauels A, Xia Y, Bex V, Midgley P (eds) Climate Change 2013: The Physical Science Basis. Contribution of Working Group I to the Fifth Assessment Report of the Intergovernmental Panel on Climate Change. Cambridge University Press, Cambridge, United Kingdom and New York, NY, USA, p 317-382

von Humboldt A (1845) Kosmos. Entwurf einer physischen Weltbeschreibung. Bd. 1. Cotta Stuttgart u. Tübingen

Wanner H, Beer J, Bütikofer J, Crowley TJ, Cubasch U, Flückiger J, Goosse H, Grosjean M, Joos F, Kaplan JO, Küttel M, Müller SA, Prentice IC, Solomina O, Stocker TF, Tarasov P, Wagner M, Widmann M (2008) Mid- to Late Holocene climate change: An overview. Quaternary Sci Rev 27(19-20):1791-1828

WGMS (2008) Global Glacier Changes: Facts and figures. UNEP, World Glacier Monitoring Service, Zurich, Switzerland

WGMS (2015) Global Glacier Change Bulletin No. 1 (2012-2013). World Glacier Monitoring Service, Zurich, Switzerland

Wild M, Ohmura A, Makowski K (2007) Impact of global dimming and brightening on global warming. Geophys. Res. Lett. 34(4): L04702. doi: 10.1029/2006GL028031

Wolken GJ (2006) High-resolution multispectral techniques for mapping former Little Ice Age terrestrial ice cover in the Canadian High Arctic. Remote Sens Environ 101(1):104114

Wolken GJ, England JH, Dyke AS (2008) Changes in late-Neoglacial perennial snow/ice extent and equilibrium-line altitudes in the Queen Elizabeth Islands, Arctic Canada. Holocene 18(4):615-627

Zemp M, Paul F, Hoelzle M, Haeberli W (2008) Alpine glacier fluctuations 1850-2000: An overview and spatio-temporal analysis of available data and its representativity. In: Darkening Peaks: Glacier Retreat, Science, and Society. B. Orlove, B. Luckman, E. Wiegandt (Eds.). University of California Press, Berkeley and Los Angeles, p 152-167

Zemp M, Hoelzle M, Haeberli W (2009) Six decades of glacier mass balance observations - a review of the worldwide monitoring network. Ann Glaciol 50:101-111

Zemp M, Zumbühl H, Nussbaumer SI, Masiokas MEL, Pitte P (2011) Extending glacier monitoring into the Little Ice Age and beyond. PAGES news 19(2):67-69

Zemp M, Frey H, Gärtner-Roer I, Nussbaumer SU, Hoelzle M, Paul F, Haeberli W, Denzinger F, Ahlstrøm AP, Anderson B, Bajracharya S, Baroni C, Braun LN, Cáceres BE, Casassa G, Cobos G, Dávila LR, Delgado Granados H, Demuth MN, Espizua L, Fischer A, Fujita K, Gadek B, Ghazanfar A, Hagen JO, Holmlund P, Karimi N, Li Z, Pelto M, Pitte P, Popovnin VV, Portocarrero CA, Prinz R, Sangewar CV, Severskiy I, Sigurðsson 

decline in the early 21st century. J Glaciol 61(228):745-762 125jährigen Jubiläum des SAC. Die Alpen 64(3):129-322

\section{Figure captions}

\section{Fig. 1}

Glacier forefields of Mutt (inset left) and Dammaglacier with moraines from the latest LIA maximum extent around 1850 (solid white arrows), the 1930s (dotted white) and 1980s (black). Dotted black lines indicate current glacier extent. Short white arrows for Dammaglacier (upper right corner) indicate a possible larger extent before 1850. The inset map in the lower right shows the location of Mutt (M), Damma (D) and Findelenglacier (F), the latter being displayed in Fig. 2. The image of Muttglacier is a satellite image (screen-shot from Google Earth), the Dammaglacier image is based on aerial photography (screen-shot from map.geo.admin.ch).

\section{Fig. 2}

Findelen Glacier in Switzerland has a series of further lateral moraines (arrows) outside the dominant moraine from its latest advance in the mid-19th century. The image is a screen-shot from Google Earth.

\section{Fig. 3}

Global glacier distribution from the Randolph Glacier Inventory with colour-coding giving mean elevation (from Bolch and Christiansen 2014).

\section{Fig. 4}

Schematic sketch of glacier response to climate change for glaciers of different size in mountain ranges of different height (from Vaughan et al. 2013).

Fig. 5

Glacier length changes since the end of the LIA for selected glaciers in the Alps. For a global overview see Vaughan et al. (2013) that is also available online at: 
1001

1002 Figures

1003

1004

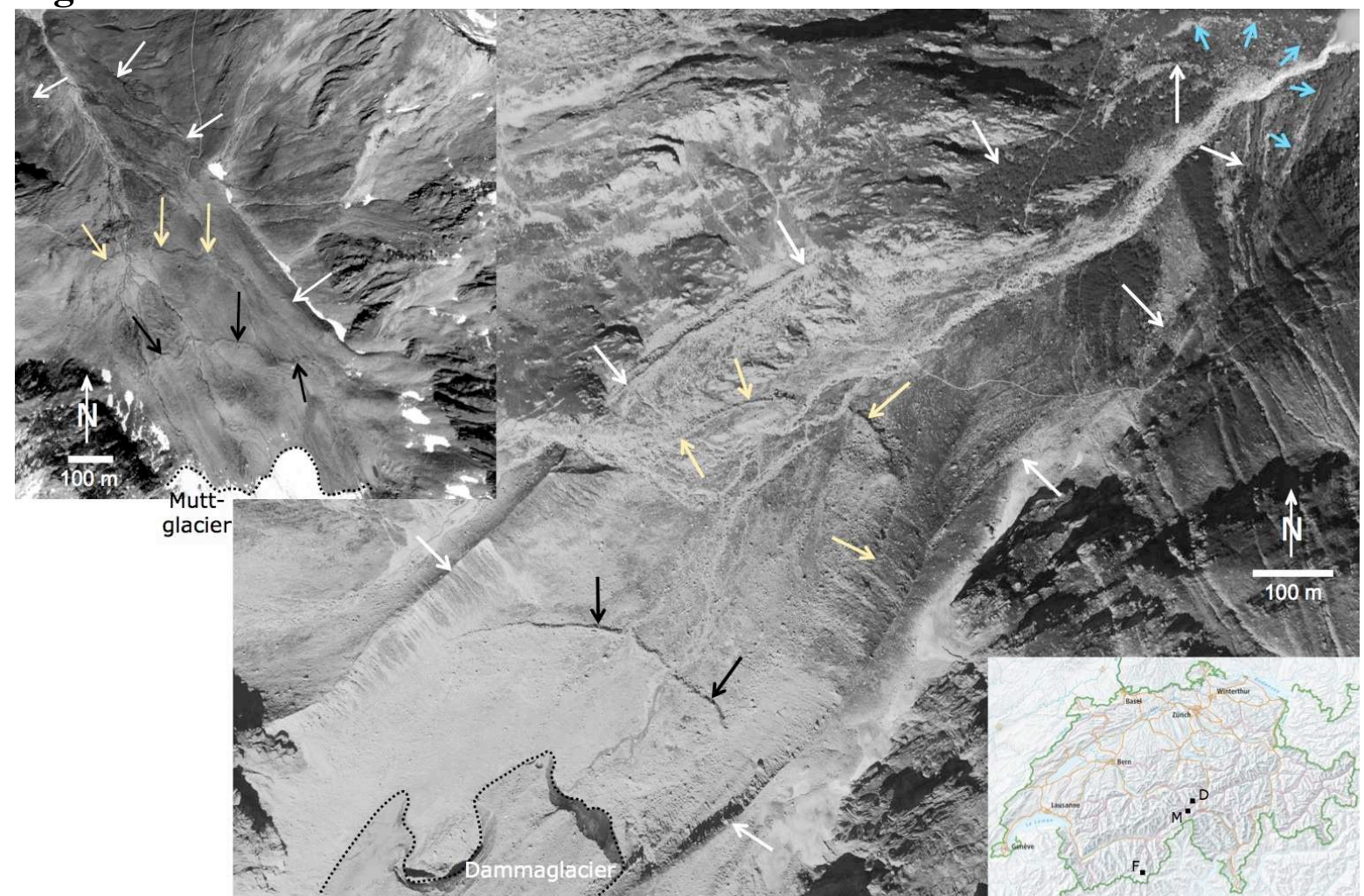

1005

1006

Fig. 1

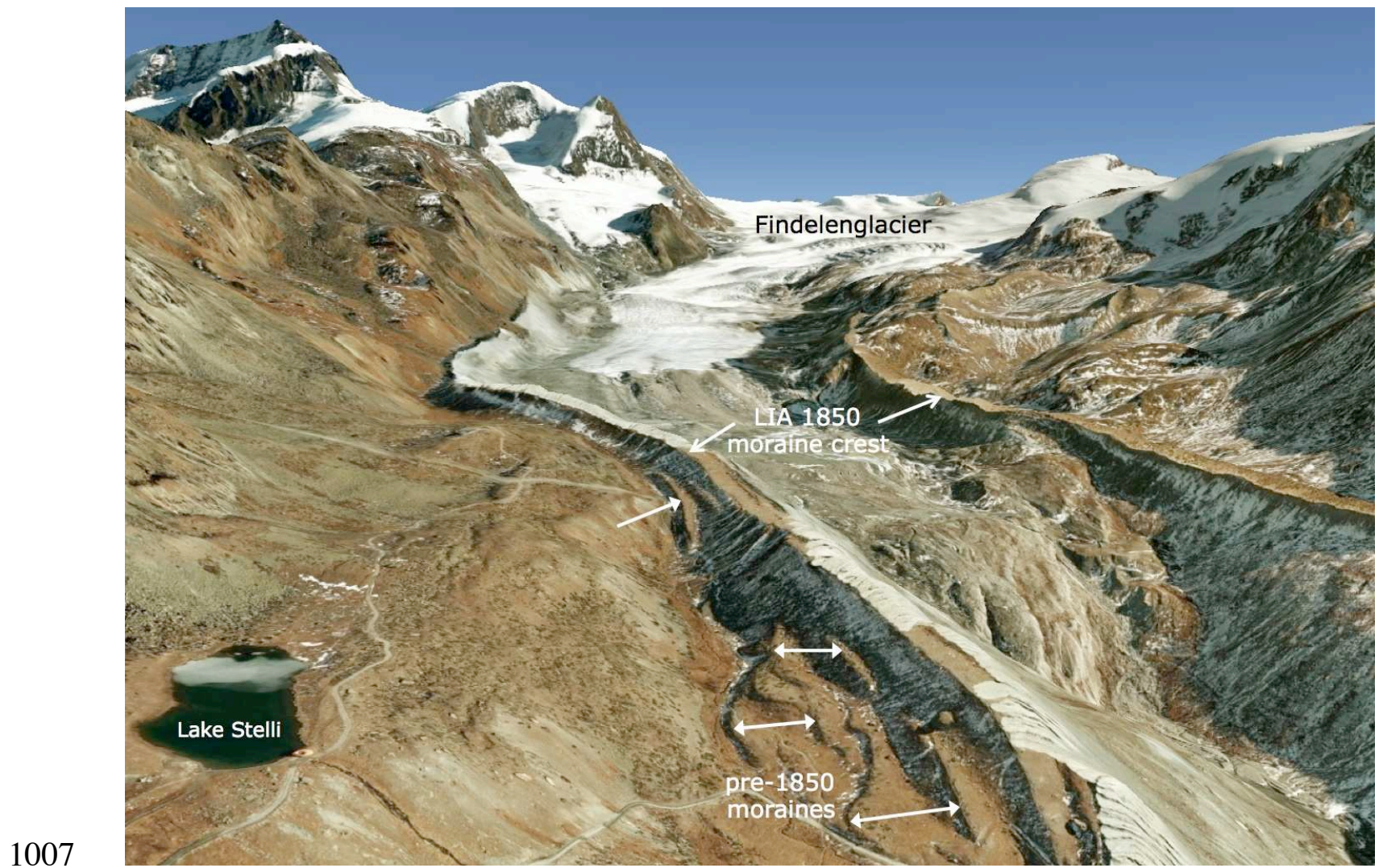

1008

Fig. 2

1009 


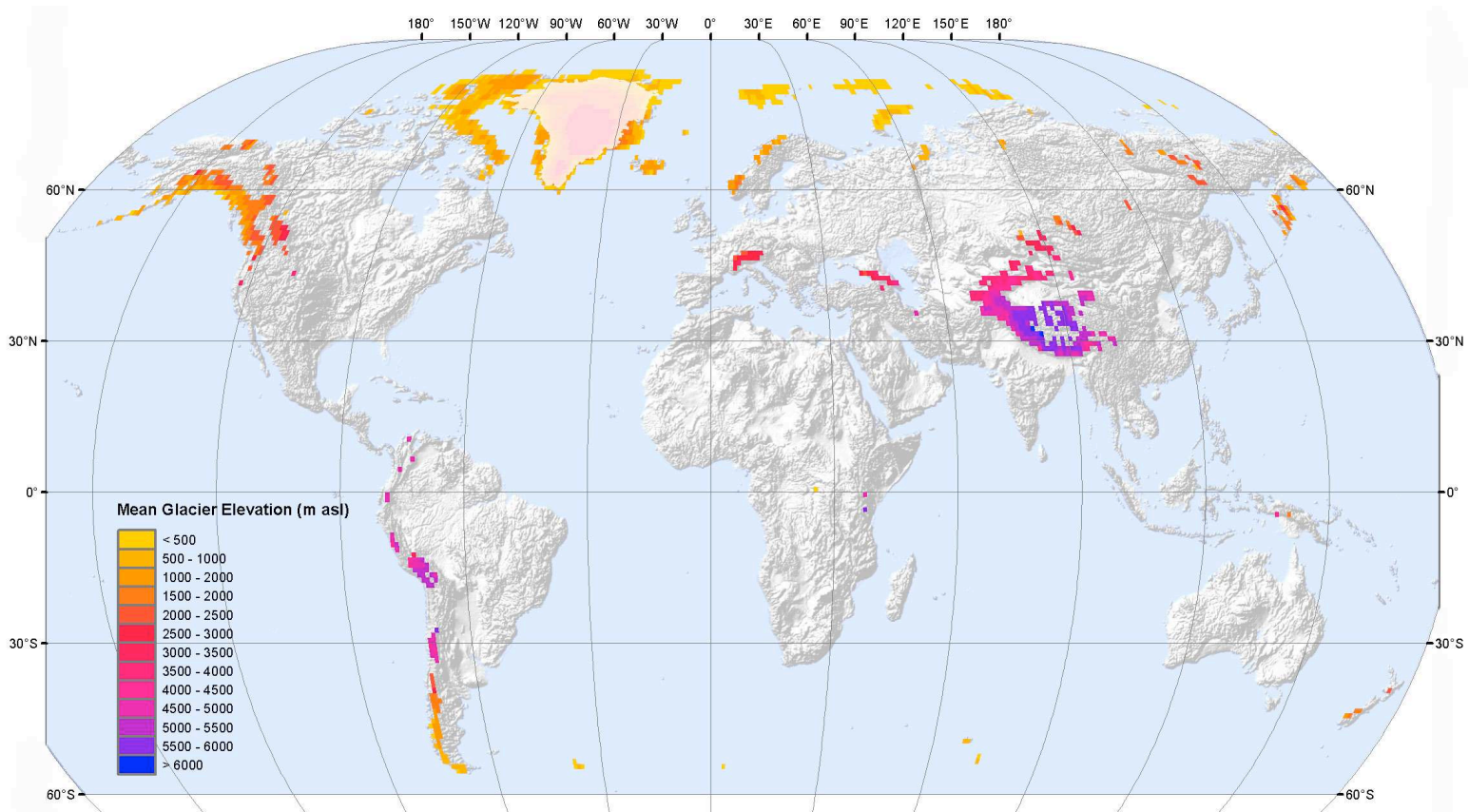

Fig. 3

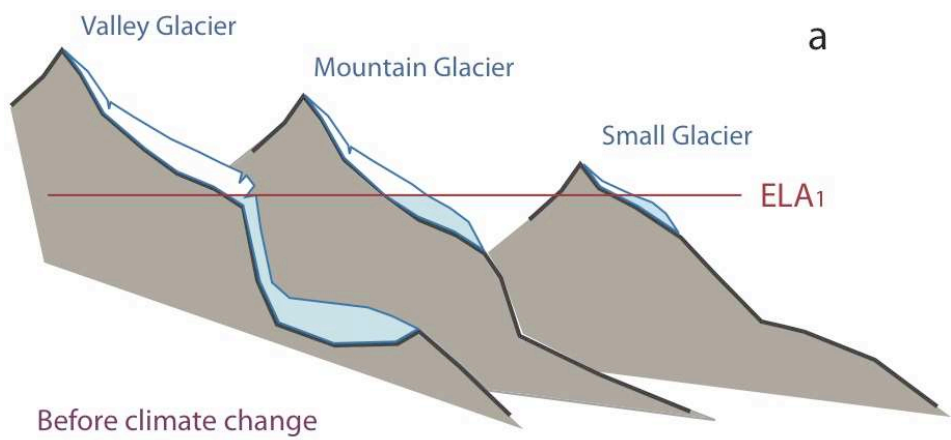

b

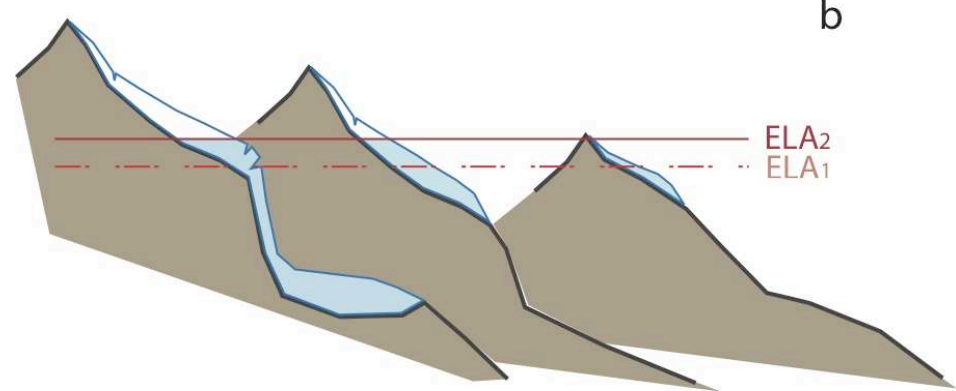

After climate change but before glacier readjustment

C

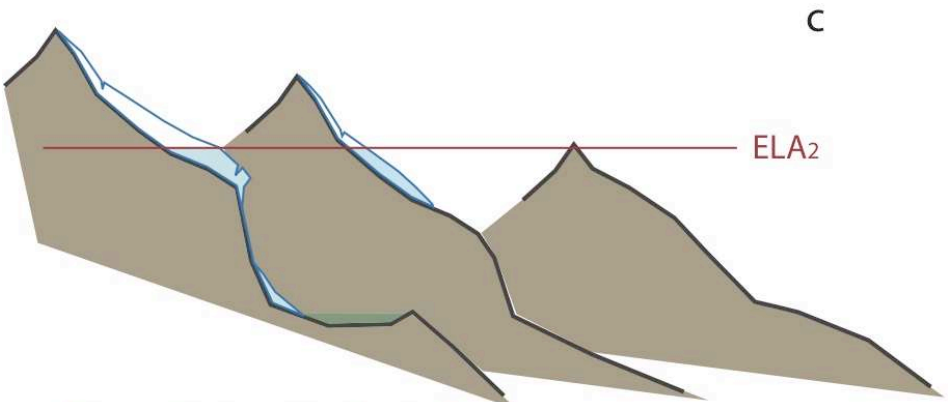

Fig. 4 


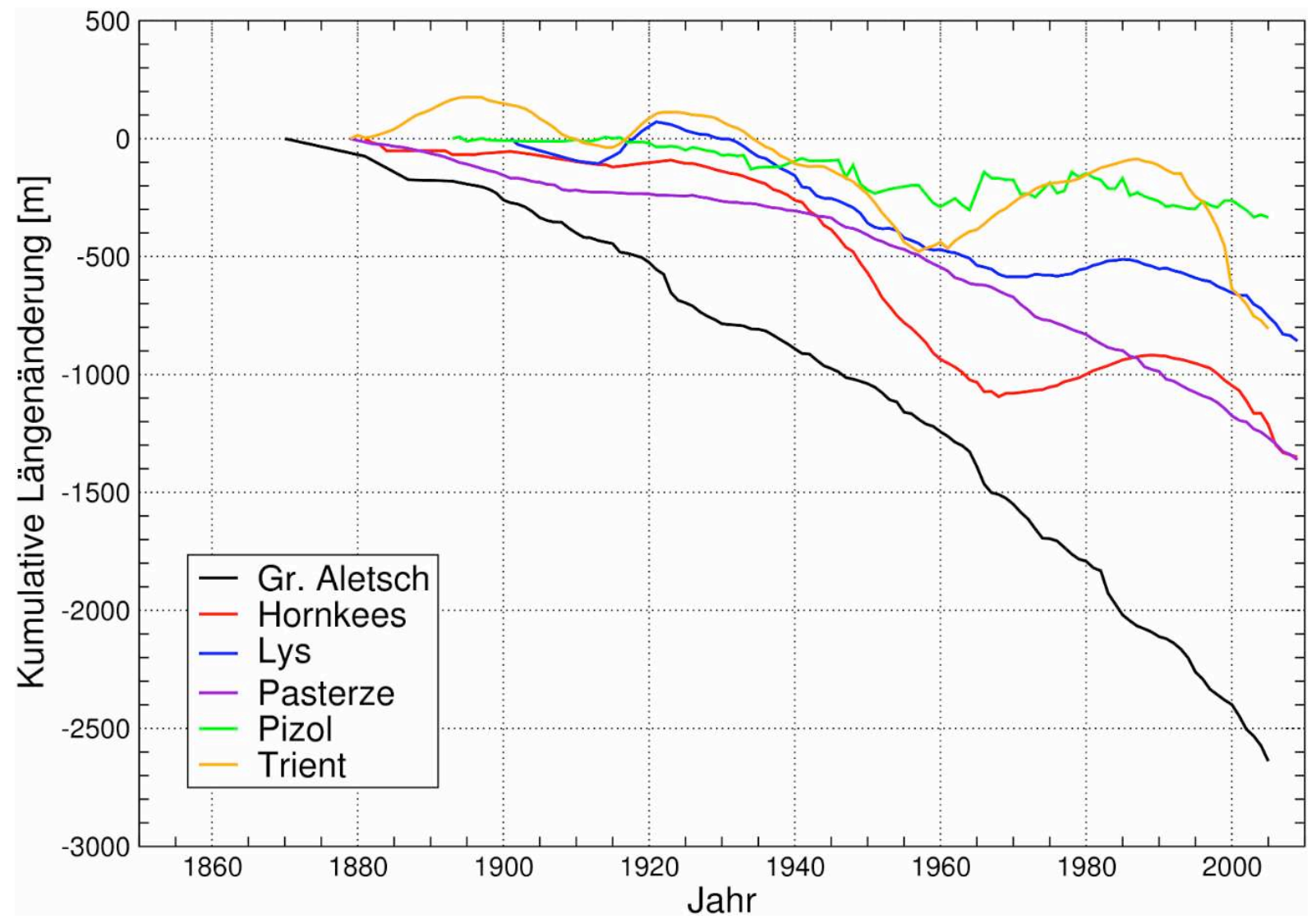

1017 Fig. 5

1018

1019 